\title{
IAMJ
}

INTERNATIONAL AYURVEDIC MEDICAL JOURNAL

\section{A REVIEW ON TOXICITY OF SNUHI (EUPHORBIA NERIFOLIA LINN.)}

\author{
$\underline{\text { Manish Rajak }}^{* 1}$, $\underline{\text { Praveen Kumar }}^{2}, \underline{\text { Ramesh Prasad }}^{3}$ \\ ${ }^{* 1,2}$ Post Graduate Scholar, Dept. of Agada Tantra Evam Vidhi Vaidyaka \\ Government Ayurvedic College Patna-800003, India \\ ${ }^{3}$ Asst. Prof. Department of Agada Tantra Evam Vidhi Vaidyaka \\ Government Ayurvedic College Patna-800003, India
}

Corresponding Author: rajak.manish51@gmail.com

https://doi.org/10.46607/iamj04p5052021

(Published online: July 2021)

Open Access

(C) International Ayurvedic Medical Journal, India 2021

Article Received:26/07/2021 - Peer Reviewed:28/07/2021 - Accepted for Publication:29/07/2021

Check for updates

\section{ABSTRACT}

Snuhi (Euphorbia nerifolia Linn.) is a widely known poisonous medicinal plant in Ayurveda. It is categorized under Sthavara Upavisha. In Ayurveda, Upavisha is the group of drugs that are less toxic and not so lethal but produces certain toxic symptoms on consumption or administration. Snuhi is one among the Upavisha and a wellknown plant in the Indian system of medicine. In the Ayurveda concept, it is believed that toxic material may be useful in various diseases if it is administered properly and similarly even a drug if not administered properly becomes an acute poison. The present review article highlights overall information about the plant Snuhi, its toxicological aspect, management, medico-legal aspect.

Keywords: Snuhi, Upavisha, Toxicological aspect

\section{INTRODUCTION}

Agada Tantra is one among the branch of Ashtang Ayurveda which narrates with detail study of Visha (poisons). Visha ${ }^{(1)}$ are classified in to 2 type Sthavara and Jangama. SthavaraVisha ${ }^{(2)}$ is again classified into two 2 subtypes Visha and Upavisha. Snuhi is a well-known medicinal plant in the Indian system of medicine. It has been stated categorically that strong poisons could be the best medicine, if it is used after proper Shodhana, in a proper therapeutic dose and formulation. On the contrary, a good medicine may 
affect adversely unless it is used for a proper person with proper dose $\mathrm{e}^{(3)}$. Rasatarangani mentioned eleven types of Upavisha ${ }^{(4)}$ and Snuhi is one among them. In Ayurvedic literature, Upavisha is the group of drugs that were less toxic and not so lethal but produce certain toxic symptoms on consumption or administration. They are having less toxic potency ${ }^{(5)}$. Snuhi is also identified as Guda, Sudha, Vajri, Sehunda, Samanta Dugdha, Sudha, all these are the Synonyms words used in the classics for the milky exudates of Euphorbia nerifolia ${ }^{(6)}$.

Botanical Name $^{(7)}$ : Euphorbia nerifolia linn.

Family: Euphorbiaceae

Vernacular Name ${ }^{(7)}$ :

Hindi Name: Sehund, Danda, Thukar

English Name: Common milk hadge

Telugu: Akujemudu

Tamil: Ilaikalli

Type of Poison:

Ayurveda ${ }^{(8)}$ : SthavaraVisha

Modern ${ }^{(9)}$ : Irritant poison

Classical categarisation ${ }^{(10)}$ :

Caraka: Virecana, Sat Sodhana Vrksa

Sushruta: Syamadi, Adhobhagahara

Vagbhata: Nikumbhadi (Virecana)

Species $^{(11)}$ :

- E. nerifolia Linn. - Patra Snuhi

- E. nivula Buch. - Ham

- E. antiquorum Linn. - TridharaSehunda

- E. trigona Haw-TridharaSehundaBheda

- E. royleanaBoiss - Thuhara

- E. tirucalli-Kanda Snuhi

Distribution ${ }^{(12)}$ : Plant occurs commonly in the rocky ground throughout the Deccan, Peninsula and is often cultivated for hedges in villages throughout India.

Plant description: Large succulent shrub or a small tree or which grows up to $20 \mathrm{ft}$. high, with jointed, cylindrical, or obscurely 5-angled branches bearing short stipular thorns, more or less confluent in vertical or slightly spiral lines. Flowers-yellowish green or greenish yellow in colour. Leaves- fleshy, deciduous, 6-12 inches long. Fruits tricolcus, consisting of appearing three radiating follicles. Seeds- minute like rape seeds.
- Flowering and Fruiting time - The plant becomes leafless during winter. Flowers begin to appear in springs and subsequently plant bears fruits.

Toxic Chemical Constituents ${ }^{(13)}$ :

- Nerifoliol, Nerifolene, Euphorbin, Calcium malate, Euphol.

Rasa Panchaka ${ }^{(14)}$ :

- Rasa: Katu

- Guna: Laghu, Tikshna, Snighdha

- Virya: Ushna

- Vipaka: Katu

- Karma: Kapha-Vatahara, Dipana, Recana

Toxic Part ${ }^{(15)}$ : An acrid milky juice exuded from the stem

Fatal Dose $^{(15)}$ : A teaspoonful of juice

Fatal Period $^{(15)}: 3$ days

Toxic Signs and Symptoms ${ }^{(16)}$ :

External Application:

- When applied to the skin, produces vesication.

- When dropped into the eyes, it produces inflammation involving eyesight.

Internal Administration:

- It's causing irritants, vomiting, diarrhoea.

- Convulsions and coma.

- It is used for procuring criminal abortion.

Treatment ${ }^{(16)}$ :

- Stomach wash.

- Administration of drugs indicated by symptoms.

Post-mortem appearance ${ }^{(16)}$ :

- Gangrenous patches in the stomach.

- The spleen may be found in a rotten condition.

Medico-legal importance:

- It is used for procuring criminal abortion.

- It is rarely for homicidal purposes.

\section{DISCUSSION}

Snuhi is a well-known medicinal plant in the Indian system of medicine. It has been stated categorically that strong poisons could be the best medicine, if it is used after proper Shodhana, in a proper therapeutic dose and formulation. On the contrary, a good medicine may affect adversely unless it is used for a proper person with proper dose. Rasatarangani mentioned 
eleven types of Upavisha ${ }^{(17)}$ and Snuhi is one among them. In Ayurvedic literature, Upavisha is the group of drugs that were less toxic and not so lethal but produce certain toxic symptoms on consumption or administration. They are having less toxic potency. The present review article highlights overall information about the plant Snuhi.

\section{CONCLUSION}

In Ayurveda, Upavisha is the group of drugs that are less toxic and not so lethal but produces certain toxic symptoms on consumption or administration. Snuhi is one among the Upavisha and a well-known plant in the Indian system of medicine. In the Ayurvedic concept, it is believed that toxic material may be useful in various diseases if it is administered properly and similarly even a drug if not administered properly becomes an acute poison. So, there is a necessity to have more knowledge regarding its toxic properties, its adverse effects, and its therapeutical effect, which plays a great role in managing this toxic drug.

\section{REFERENCES}

1. Shastri Kaviraja Ambikadutta, Sushruta Samhita, Kalpasthana Chapter-2, Chaukhambha Sanskrit Sansthan, Varanasi Part I Edition: Reprint, 2016, 18p.

2. Sharma Pracharya Shri Sadanand, Rasatarangani Vishopavishadi Vigyaniya, Chapter-24, Motilal Banarasidas Varanasi Eleven Edition: 1979, 648p.

3. Agnivesh Charak Samhita Edited by Vaidya Yadavji Trikramji Acharya, Chaukhambha Surabharti Prakashan Varanasi 2008.

4. Sharma Pracharya Shri Sadanand, Rasatarangani, Vishopavishadi Vigyaniya Chapter-24, Motilal Banarasidas, Varanasi Eleven Edition: 1979, 676p.

5. Dr. Namburi Shekhar U.R A Textbook of Agadtantra Chaukhambha Sanskrit Sansthan, Varanasi Reprint 2013,16p.

6. Dr Sastri J. L. N. Dravyaguna Vijnana Part-II Chaukhambha Orientalia, Varanasi Reprint Edition: 2012, 924p.

7. Dr Sastry J. L. N. Dravyaguna Vijnana Vol. II Chaukhambha Orientalia Varanasi Reprint Edition: 2012, $924 \mathrm{p}$.
8. Shastri Kaviraja Ambikadutta Sushruta Samhita Kalpasthana Chapter-2 Chaukhambha Sanskrit Sansthan Varanasi Part I Edition: Reprint, 2016, 21p.

9. Dr K. Shobha Bhat. A Textbook of AGADATANTRA Chaukhambha Orientalia Varanasi First Edition: 2018, 134p.

10. Dr SastryJ. L. N. Dravyaguna Vijnana Vol. IIChaukhambha Orientalia Varanasi Reprint Edition: 2012, 925p.

11. Dr Sastry J. L. N.Dravyaguna Vijnana Vol. IIChaukhambha Orientalia Varanasi Reprint Edition: 2012, 924p.

12. Dr Pandey Gyanendra Dravyaguna Vijnana part-III Chaukhambha Krishnadas Academy Varanasi Reprint Edition: 2004, 500p.

13. Dr K. Shobha Bhat. A Textbook of AGADATANTRA Chaukhambha Orientalia Varanasi First Edition: 2018, 135p.

14. Dr Sastry J. L. N. Dravyaguna Vijnana Vol. II Chaukhambha Orientalia Varanasi Reprint Edition: 2012, 925p.

15. Modi Jaising P A Textbook of Medical Jurisprudence and Toxicology *Lexis Nexis*, 26 ${ }^{\text {th }}$ Edition 2018, $163 p$.

16. Dr K. Shobha Bhat. A Textbook of AGADATANTRA Chaukhambha Orientalia Varanasi First Edition: 2018, 135p.

17. Modi Jaising P A Textbook of Medical Jurisprudence and Toxicology *Lexis Nexis*, 26 $6^{\text {th }}$ Edition 2018163p.

\section{Source of Support: Nil Conflict of Interest: None Declared}

How to cite this URL: Manish Rajak et al: A Review On Toxicity Of Snuhi (Euphorbia Nerifolia Linn.). International Ayurvedic Medical Journal \{online\} 2021 \{cited July, 2021\} Available from: http://www.iamj.in/posts/images/upload/2982_2984.pdf 